\title{
An Extracellular Blood-anticoagulant Glycopeptide Produced Exclusively during Vegetative Growth by Myxococcus xanthus and Other Myxobacteria Is Not Co-regulated with Other Extracellular Macromolecules
}

\author{
By PHILIPPE J. MASSON ${ }^{1}$ and J. F. GUESPIN-MICHEL ${ }^{2 *}$ \\ ${ }^{1}$ Laboratoire de Génétique Microbienne, Université de Technologie de Compiègne, \\ BP 233-60206, Compiègne, France \\ ${ }^{2}$ Laboratoire de Microbiologie, Université des Sciences et Techniques de Rouen, \\ BP 118-76134, Mont-Saint-Aignan Cedex, France
}

(Received 20 July 1987; revised 6 October 1987)

\begin{abstract}
We have shown that the blood anticoagulant activity (BAA) secreted by Myxococcus xanthus (designated myxaline) is a heat-stable molecule; a high-molecular-mass extracellular fraction also with an apparent BAA is a thermolabile protease. This property allowed us to assay the BAA content in crude boiled culture supernatants and to study the conditions under which it is produced. Heat-stable BAA is strictly extracellular and its production is restricted to vegetative growth in $M$. xanthus. Unlike the other extracellular proteins, its production is not affected by mutations that regulate secretion; mutations that modify the extracellular proteolytic activity do not modulate the amount of myxaline produced either. Several other species of Myxococcus and one other myxobacterial species produce a heat-stable BAA during vegetative growth.
\end{abstract}

\section{INTRODUCTION}

Myxobacteria are Gram-negative bacteria notable for their ability to undergo a morphogenetic multicellular development upon nutrient starvation (Wireman \& Dworkin, 1975). They move by gliding (Kaiser et al., 1979) and produce numerous extracellular molecules.

All species of myxobacteria produce extracellular proteins. Some of these, most notably the proteases (Gnosspelius, 1978; Coletta \& Miller, 1986) have been studied in Myxococcus xanthus and $M$. virescens. All species also produce slime, the sugar composition of which differs slightly from one species to another and is roughly constant throughout growth and morphogenesis (Sutherland \& Thomson, 1975; Sutherland, 1979). In addition numerous strains produce, during the growth phase, antibiotics and other secondary metabolites, the nature of which differs greatly not only between species but also from strain to strain (Gerth et al., 1983; Reichenbach et al., 1987).

A glycopeptide with blood anticoagulant activity (BAA) has recently been purified from the supernatant of growing cells of $M$. xanthus (El Akoum et al., 1987) and designated myxaline. Its biological activity was studied at different stages of coagulation and differed from that of heparin (El Akoum, 1987). In this paper we have investigated further the properties of this BAA.

\section{METHODS}

Bacterial strains. These are listed in Table 1.

Media and growth conditions. The bacteria were grown in Erlenmeyer flasks under rotating agitation at 300 r.p.m. in CTT medium [ $1 \%$, w/v, Casitone (Difco); $10 \mathrm{mM}-\mathrm{Tris} / \mathrm{HCl} ; 1 \mathrm{mM}-\mathrm{KH}_{2} \mathrm{PO}_{4} / \mathrm{K}_{2} \mathrm{HPO}_{4} ; 0.2 \%$, w/v, $\mathrm{MgSO}_{4} .7 \mathrm{H}_{2} \mathrm{O} ; \mathrm{pH} 7.6$ ] at $30^{\circ} \mathrm{C}$ (Bretscher \& Kaiser, 1978). Myxospore formation was induced by the technique

Abbreviations: PA, proteolytic activity; BAA, blood-anticoagulant activity; PMSF, phenylmethylsulphonyl fluoride; 2-ME, 2-mercaptoethanol. 


\section{Table 1. Bacterial strains}

Y, yellow; T, tan; Fru, fruiting body formation; Mot, motile; Muc, mucus; Exc, excretion.

Strain

Myxococcus xanthus

CM001

CM005

CM011

CM019

DZ1

CM101

CM102

CM103

CM2050

CM2053

CM2056

CM2057

DK1622

Mxx12

CM500

Myxococcus fulvus

Mxf16

CM700

Myxococcus stipatus

Mxs1

CM800

Stigmatella aurantiaca

Myxococcus virescens
Relevant characteristics

Source or reference
Derived from DK101 Y $\mathrm{Fru}^{+} \mathrm{Mot}^{+-} \mathrm{Muc}^{+} \mathrm{Exc}^{+}$

CM001: : Tn5

CM001::Tn5

CM001::Tn5

T Fru- $\mathrm{Mot}^{-} \mathrm{Muc}^{-} \mathrm{Str}^{-} \mathrm{Exc}^{-}$

DZ1 : :Tn5

DZ1::Tn5

DZ1 : :Tn5

DZ1::pME305

CM101 : :pCM2019

CM101::pCM2019

CM101::pCM2019

Y Fru+ $\mathrm{Mot}^{+} \mathrm{Exc}^{+}$

Myxalamid-producing strain

Mxx12 Str ${ }^{r}$

Myxothiazol-producing strain Mxf16 Str ${ }^{r}$

Mxsl Str
Hodgkin \& Kaiser (1979)

Nicaud et al. (1984)

Guespin-Michel et al. (1984)

Nicaud et al. (1984)

Zusman et al. (1978)

\}

This laboratory

Hodgkin \& Kaiser (1977)

Gerth et al. (1983)

This laboratory

Gerth et al. (1980)

This laboratory

Reichenbach et al. (1987)

This laboratory

Kunze et al. (1984)

Reichenbach et al. (1987)

of Dworkin \& Gibson (1964). Glycerol (10 M) (Merck) was added to an exponential phase culture to a final concentration of $0.5 \mathrm{M}$.

Bacteria were also grown in Petri dishes according to Kuner \& Kaiser (1982). Exponentially growing $M$. xanthus strain DK 1622 was diluted to $10^{7}$ cells $\mathrm{ml}^{-1}$ and dispersed into polystyrene Petri dishes (10 ml CTT) and left standing undisturbed at $30^{\circ} \mathrm{C}$ for $24 \mathrm{~h}$. The cells adhered to the bottom of the dish and the growth medium was removed by aspiration. Fruiting body formation was then induced by addition of $10 \mathrm{ml}$ per dish $1 \mathrm{mM}-\mathrm{CaCl}_{2}$ in $10 \mathrm{mM}-\mathrm{MOPS} / \mathrm{NaOH}$ (pH 6.8). Fruiting bodies containing myxospores were formed within $72 \mathrm{~h}$.

Analytical methods. (i) Protease assay. (Millet, 1970.) Protease activity was assayed using the synthetic substrate azocasein (Sigma) at a concentration of $0.5 \%(\mathrm{w} / \mathrm{v})$ in $0.1 \mathrm{M}-\mathrm{Tris} / \mathrm{HCl}(\mathrm{pH} 8.0)$. The sample $(1 \mathrm{ml})$ was added to $1 \mathrm{ml}$ of azocasein solution and the mixture was incubated at $37^{\circ} \mathrm{C}$ for $30 \mathrm{~min}$. The reaction was stopped by the addition of $10 \%(\mathrm{w} / \mathrm{v})$ trichloroacetic acid $(2 \mathrm{ml})$. After standing at $4{ }^{\circ} \mathrm{C}$ for $30 \mathrm{~min}$ the mixture was centrifuged for $20 \mathrm{~min}$ at $6000 \mathrm{~g}$ and $1 \mathrm{ml} 0.5 \mathrm{M}-\mathrm{NaOH}$ was added to $1 \mathrm{ml}$ of the supernatant. One unit (UA) of protease activity is defined as the amount of enzyme that hydrolysed $1 \mathrm{mg}$ azocasein in $30 \mathrm{~min}$ at $37^{\circ} \mathrm{C}$.

(ii) Protein assay. (Sedmak \& Grossberg, 1977.) Extracellular protein concentration was measured by the addition of $0.5 \mathrm{ml}$ Coomassie blue G (Sigma) $(0.06 \%$, w/v, in $0.6 \mathrm{M}-\mathrm{HCl})$ to $0.5 \mathrm{ml}$ of sample. The ratio $A_{620} / A_{465}$ was used to determine protein concentration; BSA was used as a standard.

(iii) Carbohydrate assay. (Haska \& Stahl, 1971.) The amount of polysaccharide in the culture supernatant was estimated by the anthrone method with glucose as a standard, and is expressed as glucose equivalents $\left(G_{e q} ; \mu \mathrm{g}\right.$ $\mathrm{ml}^{-1}$ ). To minimize the effect of free sugars and substances other than polysaccharides on the colour reaction, the polysaccharides were precipitated from the culture solution by the addition of $3 \mathrm{vols} 95 \%(\mathrm{v} / \mathrm{v})$ ethanol; after storing at $-20^{\circ} \mathrm{C}$ overnight the polysaccharides were collected by centrifugation $(5000 \mathrm{~g}$ for $10 \mathrm{~min})$ and suspended in distilled water to a suitable dilution. The sample $(1 \mathrm{ml})$ was then added to $2 \mathrm{ml}$ of anthrone solution (Sigma) at $0.2 \%(\mathrm{w} / \mathrm{v})$ in $\mathrm{H}_{2} \mathrm{SO}_{4}$ at $0{ }^{\circ} \mathrm{C}$. The mixture was heated for $16 \mathrm{~min}$ at $90^{\circ} \mathrm{C}$. The absorbance was measured at $625 \mathrm{~nm}$.

(iv) Anticoagulant activity. This was assayed by recalcified plasma clotting time, with a KC10 Dade coagulometer, using heparin (Roche) as reference. Plasma $(0.1 \mathrm{ml})$ was incubated with $0.1 \mathrm{ml}$ of sample in Michaelis buffer ( $25 \mathrm{mM}$-sodium barbital, $40 \mathrm{mM}$-sodium acetate, $100 \mathrm{mM}$-sodium chloride; $\mathrm{pH} \mathrm{7.3)} \mathrm{for} 5 \mathrm{~min}$ at $37^{\circ} \mathrm{C}$. Then $0.1 \mathrm{ml} 30 \mathrm{~mm}-\mathrm{CaCl}_{2}$ was added. One international unit (UI) is defined as the amount of product that increases the clotting time by as much as one heparin unit. The sample was either ethanol-precipitated ( 3 vols $95 \%, \mathrm{v} / \mathrm{v}$, ethanol) material or an ultrafiltrate on Amicon membrane (cut-off as described) of a culture 


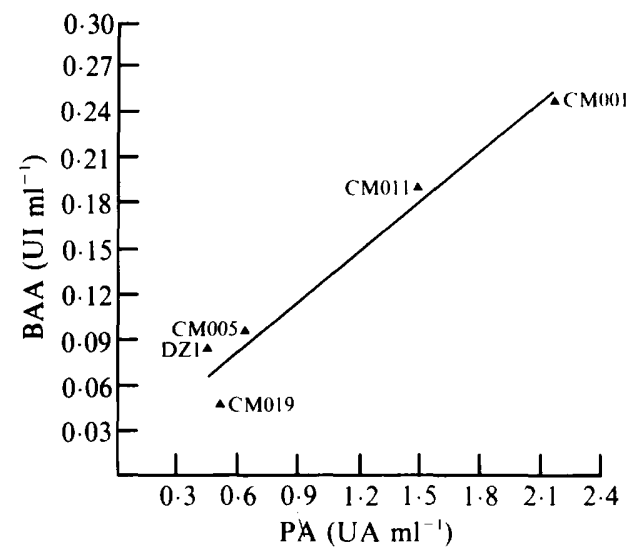

Fig. 1. Correlation between PA and BAA in ethanol-precipitated culture supernatants of various mutants of $M$. xanthus.

supernatant. Cell-bound anticoagulant activity was assayed on whole cells extracted with phenol (final concentration $25 \%, \mathrm{w} / \mathrm{v}$ ), the aqueous phase being precipitated with $95 \%$ ethanol.

Chemicals. Phenylmethylsulphonyl fluoride (PMSF) was purchased from Sigma and 2-mercaptoethanol (2-ME) from Merck.

\section{RESULTS}

$A$ heat-stable fraction of total extracellular BAA parallels myxaline production

El Akoum et al. (1987) showed that purified myxaline never exceeded 10 to $20 \%$ of the total BAA of the culture supernatant, whatever the method used for its purification. In addition the remaining BAA co-eluted with high-molecular-mass and/or low-affinity material during purification of myxaline on a pseudo-affinity column (histidyl-Sepharose 4B) (Vijayalakshmi et al., 1986) from crude concentrated culture supernatant (unpublished results). Thus either a highmolecular-mass precursor or a complex of myxaline is present in the supernatant, or another molecule is able to prevent blood coagulation in our assay. The most obvious candidates for the latter hypothesis are the extracellular proteases produced by $M$. xanthus. In order to test this hypothesis, we checked the correlation between proteolytic activity (PA) and total BAA, when the former was decreased by mutations (Fig. 1), or by inactivating treatments (Table 2). The majority of the BAA was found to be due to high-molecular-mass, heat-labile PA, whereas a small fraction ( $10 \%)$ of BAA was due to a heat-stable low-molecular-mass molecule. The latter activity was inactivated by $2-\mathrm{ME}$.

The properties of this activity were thus consistent with that investigated by El Akoum et al. (1987). Not all the proteolytic enzymes had the same BAA (Table 2), since heat-inactivation of the low-molecular-mass PA or its inactivation by PMSF treatment did not decrease the BAA of this fraction. Moreover, purified myxaline is indeed heat stable. This property is extremely useful for assaying myxaline in boiled crude culture supernatants, after concentration by ethanol precipitation or by ultrafiltration on a $1 \mathrm{kDa}$ cut-off Amicon membrane. Reproducible results can be obtained from these procedures. For example, assays of ethanol-precipitated supernatants of strains CM011 and CM001 gave BAA values of $0.019 \pm 0.006$ and $0.015 \pm 0.004$ UI $\mathrm{ml}^{-1}$ respectively. In addition, heat-treated concentrated supernatant was stabilized with regard to BAA as compared with untreated supernatant.

\section{Production of heat-stable BAA is not co-regulated with that of extracellular proteins or polysaccharides}

Several mutations impair the secretion of most extracellular proteins in $M$. xanthus (Nicaud et al., 1984; Breton \& Guespin-Michel, 1987). We therefore investigated the production of heatstable BAA and polysaccharides by these $\mathrm{Exc}^{+-}$or $\mathrm{Exc}^{++}$mutants. Table 3 shows that 
Table 2. Effects of various treatments on $P A$ and BAA activities from strain CM001

High-molecular-mass $(>10 \mathrm{kDa})$ and low-molecular-mass $(<10 \mathrm{kDa})$ fractions of ethanol-precipitated culture supernatant from $M$. xanthus $\mathrm{CM} 001$ were obtained by ultrafiltration on an Amicon membrane. The fractions were treated as shown and assayed for PA and BAA. Values are in units per ml of supernatant. Note that precipitation and ultrafiltration decrease the proteolytic activity of the standard (1 $\mathrm{UA} \mathrm{ml}^{-1}$ ).

\begin{tabular}{|c|c|}
\hline$>10 \mathrm{k}$ & action \\
\hline $\begin{array}{c}\text { PA } \\
\left(\mathrm{UA} \mathrm{ml}^{-1}\right)\end{array}$ & $\begin{array}{c}\mathrm{BAA} \\
\left(\mathrm{UI} \mathrm{ml}^{-1}\right)\end{array}$ \\
\hline
\end{tabular}

\begin{tabular}{|c|c|}
\hline \multicolumn{2}{|c|}{$<10 \mathrm{kDa}$ fraction } \\
\hline $\begin{array}{c}\text { PA } \\
\left(\mathrm{UA} \mathrm{ml}^{-1}\right)\end{array}$ & $\begin{array}{c}\text { BAA } \\
\left(\mathrm{UI} \mathrm{ml}^{-1}\right)\end{array}$ \\
\hline 0.22 & 0.02 \\
\hline $0 \cdot 1$ & 0.02 \\
\hline 0.06 & 0.02 \\
\hline 0 & 0.02 \\
\hline 0.03 & 0.02 \\
\hline 0 & 0 \\
\hline
\end{tabular}

Table 3. Proteins, proteases, polysaccharides and heat-stable BAA in culture supernatants from various strains and mutants of $M$. xanthus

Values are per $\mathrm{ml}$ of supernatant.

\begin{tabular}{|c|c|c|c|c|}
\hline Strain & $\begin{array}{l}\text { Proteins } \\
\left(\mu \mathrm{g} \mathrm{ml}^{-1}\right)\end{array}$ & $\begin{array}{l}\text { Proteases } \\
\left(\mathrm{UA} \mathrm{ml}^{-1}\right)\end{array}$ & $\begin{array}{l}\text { Polysaccharides } \\
\left(\mu \mathrm{g} \mathrm{Glc} \mathrm{eq.} \mathrm{ml}^{-1}\right)\end{array}$ & 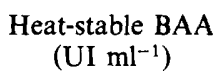 \\
\hline CM001 & $50 \pm 10$ & $3.2 \pm 0.9$ & $31 \pm 5$ & $0.015 \pm 0.004$ \\
\hline CM011 & $46 \pm 12$ & $3 \cdot 2 \pm 1$ & $35 \pm 5$ & $0.019 \pm 0.006$ \\
\hline DK 1622 & $32 \pm 4$ & $5 \cdot 3 \pm 0 \cdot 1$ & $15 \pm 2$ & $0.020 \pm 0.005$ \\
\hline CM005 & $35 \pm 8$ & $1.5 \pm 0.8$ & $22 \pm 4$ & $0.018 \pm 0.007$ \\
\hline CM019 & $39 \pm 11$ & $1.6 \pm 0.4$ & $23 \pm 8$ & $0.015 \pm 0.003$ \\
\hline DZ1 & $33 \pm 8$ & $1.3 \pm 0.5$ & $18 \pm 5$ & $0.016 \pm 0.005$ \\
\hline CM103 & $41 \pm 7$ & $2.5 \pm 0.6$ & $27 \pm 10$ & $0.014 \pm 0.003$ \\
\hline CM2050 & $54 \pm 12$ & $3 \cdot 8 \pm 0$ & $30 \pm 10$ & 0.013 \\
\hline CM2053 & $37 \pm 0$ & $1 \cdot 4 \pm 0$ & $26 \pm 4$ & 0.012 \\
\hline CM2056 & $33 \pm 4$ & $0.9 \pm 0.3$ & $24 \pm 2$ & 0.012 \\
\hline CM2057 & $36 \pm 4$ & $0.6 \pm 0$ & $26 \pm 0.5$ & 0.016 \\
\hline CM101 & $40 \pm 9$ & $0.6 \pm 0.2$ & $23 \pm 6$ & $0.017 \pm 0.009$ \\
\hline CM102 & $36 \pm 6$ & $0.8 \pm 0.2$ & $25 \pm 8$ & $0.022 \pm 0.009$ \\
\hline
\end{tabular}

polysaccharide production was affected by these mutations, but no significant correlation with myxaline production could be seen. Thus, myxaline is not controlled by the genes that regulate protein secretion.

In repeated assays we could not detect any cell-bound BAA; in addition, Table 3 shows that mutants that produce less or more proteases are not altered in their heat-stable BAA production, which indicates that at least those proteases are not involved in the production of this activity.

\section{Myxaline production is strictly restricted to vegetatively growing cells}

The lack of regulation of myxaline secretion by the genes that control protein secretion during growth of $M$. xanthus prompted us to check whether its synthesis could be developmentally regulated. Glycerol-induction of myxospores from strains CM001 and CM011 did not increase the amount of BAA in the medium. Strain DK 1622 (which is the only suitable strain for morphogenesis induction in submerged culture) produces heat-stable BAA during growth in Petri dishes, but no activity was detected after morphogenesis induction at any stage of the developmental cycle. In agreement with these results $\mathrm{Fru}^{-}$mutants are not affected in their production of BAA (Table 3). Since $\mathrm{Mot}^{+}, \mathrm{Mot}^{+-}$and $\mathrm{Mot}^{-}$strains were assayed, motility is not required for the production of myxaline. 


\section{$A$ heat-stable BAA is produced by several myxobacterial species}

Since all the strains we have assayed are derived from the same wild-type ancestor, we wondered whether myxaline could be a secondary metabolite such as those produced by many myxobacteria during vegetative growth (Reichenbach et al., 1987). Such secondary metabolites differ, not only from species to species, but even from strain to strain within the same species.

A heat-stable BAA was found in the culture supernatant of growing cells of another strain of $M$. xanthus as well as from strains of several other species of myxobacteria. The activities (UI $\mathrm{ml}^{-1}$ ) were 0.007 (M. xanthus strain CM500), 0.009 (M. virescens Mxv48), 0.011 (M. stipitatus CM800), 0.012 (M. fulvus CM750) and 0.013 (Stigmatella aurantiaca DW4).

\section{DISCUSSION}

A heat-stable extracellular BAA is produced by growing cells of several species of myxobacterales (genera Myxococcus and Stigmatella). In $M$. xanthus this activity has been purified and shown to be a glycopeptide, termed myxaline (El Akoum et al., 1987), whose production is not controlled by the genes that regulate the secretion of most extracellular proteins. Since these genes also regulate the production of extracellular polysaccharides, myxaline is unlikely to be a precursor of the slime, nor a product of proteolytic or glycosidic cleavage of this molecule. Whatever the nature of its production, it seems to be strictly restricted to the vegetative growth phase. Its production is proportional to the cell dry weight as shown by El Akoum (1987).

At least two surface glycoproteins are known in M. xanthus (Dobson \& McCurdy, 1979; Maeba, 1986). The composition of myxaline (El Akoum et al., 1987) differs from both these molecules. However, it is still possible that myxaline is derived from an as yet unidentified glycoprotein precursor.

The production of myxaline by strains from several different species of myxobacteria is not consistent with it being a secondary metabolite. As myxaline production is apparently not regulated by the mechanisms that control the secretion of most extracellular macromolecules and as activity is present in several strains and species of myxobacteria, myxaline may have a specific and important role during vegetative growth of these bacteria.

This work was supported by a grant from Agence Nationale pour la Valorisation de la Recherche (ANVAR) and by a grant from Ministère de la Recherche et de la Technologie (MRT) no. 85T0699. We thank Dr P. G. G. Miller (University of Liverpool) for reviewing the manuscript and Dr D. Gilbert (Centre de transfusion sanguine de Rouen) who kindly received us in her laboratory for assaying BAA.

\section{REFERENCES}

Breton, A. \& GUESPIN-Michel, J. F. (1987). Escherichia coli $\mathrm{pH} 2.5$ acid phosphatase and $\beta$-lactamase TEM2 are secreted into the medium by Myxococcus xanthus. FEMS Microbiology Letters $\mathbf{4 0}$, 183-188.

Bretscher, A. P. \& KaISER, D. (1978). Nutrition of Myxococcus xanthus, a fruiting myxobacterium. Journal of Bacteriology 133, 763-768.

Coletta, P. L. \& Miller, P. G. G. (1968). The extracellular proteases of Myxococcus xanthus. FEMS Microbiology Letters 37, 203-207.

Dobson, W. J. \& McCurdy, H. D. (1979). The function of fimbriae in Myxococcus xanthus. I. Purification and properties of Myxococcus xanthus fimbriae. Canadian Journal of Microbiology 25, 11521160 .

Dworkin, M. \& GIBson, S. M. (1964). A system for studying microbial morphogenesis: rapid formation of microcysts in Myxococcus xanthus. Science 146, 243-244.
EL Axoum, A. (1987). Mise en évidence d'une nouvelle substance anticoagulante d'origine bactérienne (Myxococcus xanthus). Caractérisation et propriétés biologiques in vitro. Thèse de doctorat Université de Technologie de Compiègne, France.

El Akoum, A., Vijayalakshmi, M., Cardon, P. Fournet, B., Sigot, M. \& Guespin-Michel, J. F. (1987). Myxococcus xanthus produces an extracellular glycopeptide that displays blood anticoagulant properties. Enzyme and Microbial Technology 9, 426429.

GerTh, K., IrSChIK, H., ReIChEnbach, H. \& Trowizsch, W. (1980). Myxothiazol, an antibiotic from Myxococcus fulvus (Myxobacterales). Journal of Antibiotics 35, 1474-1479.

Gerth, K., Jansen, R., Reifenstahl, G., Hofle, G., IRSCHICK, H., KUNZE, B., REICHENBACH, H. \& THIERBACH, G. (1983). The myxalamids, new antibiotics from Myxococcus xanthus (Myxobacterales). Journal of Antibiotics 36, 1150-1156. 
GNosspelius, G. (1978). Purification and properties of an extracellular protease from $M y x o c o c c u s$ virescens. Journal of Bacteriology 133, 17-25.

Guespin-Michel, J. F., BReton, A. Nicaud, J. M. \& YouNES, G. (1984). In Génétique des Microorganismes Industriels, pp. 337-341. Edited by H. Heslot. Paris: Société Française de Microbiologie.

HASKA, G. \& STAHL, S. (1971). Variants of Myxococcus virescens exhibiting dispersed growth. Growth and production of extracellular enzymes and slime. Physiologia plantarum 24, 136-142.

Hodgkin, J. \& KAISER, D. (1977). Cell to cell stimulation of movement in non motile mutants of Myxococcus. Proceedings of the National Academy of Sciences of the United States of America 74, 29382942.

HodgKin, J. \& KAISER, D. (1979). Genetics of gliding mobility in Myxococcus xanthus (Myxobacterales): genes controlling movement of single cells. Molecular and General Genetics 171, 167-176.

Kaiser, D., Manoll, C. \& Dworkin, D. (1979). Myxobacteria: cell interactions, genetics and development. Annual Review of Microbiology 33, 595-639.

KunER, J. M. \& KAISER, D. (1982). Fruiting body morphogenesis in submerged cultures of Myxococcus xanthus. Journal of Bacteriology 151, 458-461.

KunZe, B., Kemmer, T., Hofle, G. \& ReICHenbaCh, H. (1984). Stigmatellin, a new antibiotic from Stigmatella aurantiaca. I. Production, physicochemical and biological properties. Journal of Antibiotics 37, 454-461.

MAEBA, P. Y. (1986). Isolation of a surface glycoprotein from Myxococcus xanthus. Journal of Bacteriology 166, 644-650.

MiLlET, J. (1970). Characterization of proteinases excreted by Bacillus subtilis Marburg strain during sporulation. Journal of Applied Bacteriology 33, 207-219.

Nicaud, J. M., Breton, A., Younes, G. \& GuespinMichel, J. (1984). Mutants of Myxococcus xanthus impaired in protein secretion: an approach to study of a secretory mechanism. Applied Microbiology and Biotechnology 20, 344-350.

Reichenbach, H., GerTh, K., IRSChIK, H., Kunze, B. \& HoFLE, G. (1987). Myxobacteria, a source for new antibiotics. In Biotechnology of Antibiotics, Steroids and Alkaloids of Medical Importance. Edited by R. Vlahov. Weinheim: VCH Verlagsgesellschaft (in the Press).

Sedmax, J. \& Grossberg, S. (1977). A rapid sensitive and versatile assay for protein using Coomassie brilliant blue G250. Analytical Biochemistry 79, $544-552$.

SUTHERLAND, I. W. \& Thomson, S. (1975). Comparison of polysaccharides produced by Myxococcus strains. Journal of General Microbiology 89, 124-132.

SuTHERLAND, I. W. (1979). Polysaccharides produced by Cystobacter, Archangium, Sorangium and Stigmatella species. Journal of General Microbiology 111, 211-216.

Vijayalakshmi, M. A., Kanoun, S., Amourache, L. \& KRISHNAN, S. (1986). New support for the large-scale purification of proteins. Journal of Chromatography 376, 259-267.

WIREMAN, J. W. \& Dworkin, M. (1975). Morphogenesis and developmental interactions in myxobacteria. Science 189, 516-523.

Zusman, D. R., KRotoski, D. M. \& Cumsky, M. (1978). Chromosome replication in Myxococcus xanthus. Journal of Bacteriology 133, 122-129. 